\title{
Between Legal Realism and Neutral Principles: The Legitimacy of Institutional Values
}

\author{
Jon O. Newman $\nmid$
}

It is a challenging invitation to participate in Berkeley's Centenary Lectures dealing with the nature of the rule of law. My perspective is that of the judge. So when I venture to offer soine thoughts about the rule of law, I focus on law as it is pronounced by judges. The matter I will explore is the age-old inquiry as to what it is that a judge is domg when he or she endeavors to "decide" a case, especially a close case presenting a choice between two plausible, indeed, respectable, contentions of law. In considering this topic already pondered by so many, the inost I can expect is to illuminate some sinall aspect of the matter. It would be presuinptuous to claim to be doing inore. So, despite the breadth of the topic, iny concern will be rather narrow-a modest effort to suggest soine of the considerations that I believe judges have in mimd when they decide issues of law, especially nonconstitutional issues.

To confine iny focus primarily to nonconstitutional issues is admittedly to withdraw froin the great debates that have raged concerning the nature of the adjudication process as practiced by the Justices of the Supreme Court. I think iny narrower focus is justified by several considerations. First, the body of decisional law that constrams all judges other than Supreme Court Justices is doininated in important respects by the authoritative pronounceinents of the Court. For the Justices, their own rulings are precedents available for refineinent, reconsideration, and, on occasion, rejection. For the rest of us, they are precedents to be followed. Second, adjudication of constitutional issues, especially by the Supreme Court, involves consideration of a range of values of constitutional dimension, far broader im scope than the concerns that bear on most of the nonconstitutional questions adjudicated in the federal courts of appeals, the federal district courts, and the state courts. Finally, the day-to-day activity of judges serving on these courts is largely devoted to nonconstitutional business; it is therefore worth considering what influences these decisions, even if such inquiry sheds

$\dagger$ Judge, United States Court of Appeals for the Second Circuit. B.A. 1953, Princeton University; LL.B. 1956, Yale Law School. 
only scant hight upon the nature of decisionmaking by members of the Supreme Court.

The thinking that judges bring to bear in deciding issues of law is the sinew of law itself. ${ }^{1}$ Those who care deeply about the development of law concern themselves at least as much with the judge's thinking as with the judge's result. Perhaps no intellectual endeavor receives such careful scrutiny by so many able observers as the adjudication of cases, especially those decided by appellate courts. In relative isolation, by contrast, the doctor selects a course of medical treatment, the engineer designs a project, the business executive plans the inarketing of a product. Their demonstrable failures attract attention, their successes garner occasional praise, but, in either event, it is usually the result alone that is assessed. Only in an occasional graduate seminar do knowledgeable observers of their fields analyze the nature of the thinking that led to even a handful of their decisions.

We judges do our work in a rather different fishbowl. Without doubt our results attract attention, frequently the uncoinprehending attention of a public misled by news reports that highlight only results, and obscure what frequently is the underlymg legislative basis of the decision. "Court Orders Benefits for Handicapped Child," a headline reads, and only toward the end of the article, if at all, is there mention of the Act of Congress that the court was enforcing. Or "Court Bars Highway Project," the public learns, without ever finding out that the requirements of an environmental statute had not been observed.

It is the explanation for the result, however, that attracts the attention of the legal profession-judges of other courts who review the decision on appeal, or attempt to comply with it on remand, or decide whether or not to follow it in another jurisdiction; lawyers who enlist the decision when it helps, distinguish it when it hurts, and ponder it when advising a client; and especially students of the law, whether standing at the front of the classrooin or sitting at the rear. The appellate judge knows, and is never allowed to forget, that whatever expla-

1. In considering the "why" of decisionmaking, I state at once that a premise from which I proceed is that the adjudication of close questions of law is, in the main, a rational process. As will soon appear, I do not claim too much by so stating. However, I do mean to put to one side any cosmic debate about free will versus determinism. I recognize the possibihty that every decision I reach may be the inevitable result of forces at work of which I am uuaware or perbaps on oceasiou only dimly aware, that what I choose to call a rational process may in fact be a predetermined set of responses to everything that has happened in my life up to the instant of decision. To whatever extent a ratioual process is at work, this too may be bram wave activity responding in a preordained pattern to stimuli in a fashion so devious as to inake me think (some would say feel) that I had the freedom to make up my mind. If that is what is happening, then by definition I can do nothing about it. My topic is worth pursuing only if judges are free to use their minds to make choices; so I start with the premise that such freedom exists. For me, it is sufficient simply to assert: I am; therefore I think. 
nations he or she gives for a decision will be exammed by brilliant analysts, who are experts in the field to which the judge is only an occasional contributor.

\section{I}

\section{The Traditional Analyses-Legal Realism vs. Neutral Principles}

Analyses of judicial reasoning have tended to reflect a polarity of assessment. At one extreme are those legal realists who are certam that judges start with a result and articulate reasons only by way of rationalization. $^{2}$ At the other extreme are those who join with Herbert Wechsler in a never-ending search for "neutral principles" from which results may be derived by a process of reasoning. ${ }^{3}$ It will be the burden of my argument that significant aspects of adjudication lie between these extremes, and that these aspects, frequently overlooked by analysts and frequently not articulated by judges, often provide the key determinants of the decision.

Let me diminish somewhat the polarity between legal realism and neutral principles in order to fill in the context for what I have im mind. There are common aspects to both schools, not always appreciated by

2.

Now, since the judge is a human being and since no human being in his normal thinking processes arrives at decisions (except in deahing with a limited number of simple situations) by the route of any such syllogistic reasoning, it is fair to assuine that the judge, merely by putting on the judicial ermine, will not acquire so artificial a method of reasoning. Judicial judgments, like other judgments, doubtless, in most cases, are worked out backward from conclusions tentatively formulated.

J. Frank, LAW AND THE MODERn MIND 101 (1930). See also Cohen, Transcendental Nonsense and the Functional Approach, 35 CoLUM. L. REv. 809, 812 (1935); Cook, The Logical and Legal Bases of the Confict of Laws, 33 YALE L.J. 457, 486-87 (1924).

For a useful recount of the history of the legal realist movement, see W. TwiniNG, KarL LLEWELLYN AND THE REALIST MOVEMENT (1973). For soine of the notable works of this movement, see T. ARnold, The Symbols of Government (1935); K. Llewellyn, The Bramble Bush: ON OUR LaW AND ITs STUdy (1960); Frank, Are Judges Human? (pts. 1 \& 2), 80 U. PA. L. REv. 17, 233 (1931); Llewellyn, A Realistic Jurisprudence-The Next Step, 30 ColuM. L. REV. 431 (1930). For a defense of legal realism and a bibliography of its proponents, see Llewellyn, Some Realism about Realism-Responding to Dean Pound, 44 HARV. L. REV. 1222 (193I). The legal realists were not without criticisin from their contemporaries. See Adler, Legal Cerfainty, 31 Colum. L. Rev. 91 (1931); Fuller, American Legal Realism, 82 U. PA. L. Rev. 429 (1934); Kantorowicz, Some Rationalism about Realism, 43 YALE L.J. 1240 (1934); Pound, The Call for $a$ Realist Jurisprudence, 44 HARv. L. REv. 697 (1931).

3. "Neutral primciples" jurisprudence originated with Herbert Wechsler's Oliver Wendell Holmes Lecture at the Harvard Law School in 1959. Wechsler, Toward Neutral Principles of Con. stilutional Law, 73 HARv. L. REv. 1 (1959). That lecture was, im part, a response to Judge Learncd Hand's Holmes Lecture the previous year, L. HAND, THE BiLL OF RigHTS 1-30 (1962), in which Hand professed an inability to justify the antidemocratic nature of judicial review. The HandWechsler debate still rages between the "interpretivist" and "noninterpretivist" theorists. Com. pare Brest, The Misconceived Quest for the Original Understanding, 60 B.U.L. REv. 204 (1980), with Monaghan, Our Perfect Constitution, 56 N.Y.U. L. REv. 353 (1981). 
their adherents. Whether a judge reasons forward from principles or backward from a result, both a rational process and an expression of preferences are involved in varying degrees. For the legal realist, the expression of preferences predominates. In his view, the result is selected for any one of a number of reasons, or possibly on the basis of considerations that cannot even be dignified as "reasons." I doubt if many still find it fashionable to attribute judicial decisionmaking to whim or caprice, or, in the timeworn phrase, "what the judge had for breakfast." However, it is still fashionable for sone critics to attribute most judicial decisions to the judge's political, economic, or social values. In their view, the judge simply selects the result that best comports with personal values and then enlists, sonnetimes brutally, whatever doctrines arguably support the result.

A few of the more thoughtful realists espouse a more sophisticated view. ${ }^{5}$ Conscientious judges, they contend, nuake good-faith efforts to search for applicable principles of law and to reason from what the judge believes is the governing principle toward an indicated result. The problem, as the modern realists see it, is that the array of available legal principles leaves judges free to decide a close case either way. Even if judges try not to be result oriented, the law provides them witl inadequate guidance. The product is a somewhat random series of decisions that collectively form the law, but do not provide a principled basis for deciding the next close case. The fault, it is urged, lies not with the judges, but with the indeterminate nature of law itself. ${ }^{6}$ The primciples of law are too numerous, too imprecise, and too malleable. I will return to this point of view later. For now let me simply observe that even if these inodern realists are accurately describing the legal

4. See J. FRANK, supra note 2, at 111 ("law may vary with the personality of the judge who happens to pass upon any given case"); Hutcheson, The Judgment Intuitive: The Function of the "Hunch" in Judicial Decision, 14 CoRnelL L.Q. 274 (1929); Schroeder, The Psychologic Study of Judicial Opinions, 6 CALIF. L. Rev. 89 (1918).

5. I have in mind the scholars who comprise the Critical Legal Studies Movement. The Conference on Critical Legal Studies, formed in 1977, grew out of the dissatisfaction with the direction and content of "mainstream" legal scholarship. While these theorists have divergent substantive views and methodologies, they share the belief that mainstreain jurisprudence masks the essential indeterminance of law. On the connection between legal realism and critical legal studies, see Freeman, Truth and Mystification in Legal Scholarship, 90 Y ALE L.J. 1229, 1230, 1233 (1981); Tushnet, Legal Scholarship: Its Causes and Cure, 90 YALE L.J. 1205 (1981).

For some of the writings of this movement, see The Politics of LAW: A Progressive CRITIQUE (D. Kairys ed. 1982); Gabel, Intention and Structure in Contractual Conditions: Outline of a Method for Critical Legal Theory, 61 MiNN. L. REv. 601 (1977); Kelman, Interpretive Construction in the Substantive Criminal Law, 33 Stan. L. Rev. 591 (1981); Kennedy, Form and Substance in Private Law Adjudication, 89 HARv. L. Rev. 1685 (1976); Kennedy, The Structure of Blackstone's Commentaries, 28 Buffalo L. Rev. 205 (1979); Unger, The Critical Legal Studies Movement, 96 HARV. L. ReV. 561 (1983).

6. On the indeterminance of law, see, for example, Kennedy, Form and Substance in Private Law Adjudication, supra note 5, at 1732; Tuslmet, supra note 5, at 1211-15. 
system (and I have serious reservations on that score), they are telling us very little about how a judge makes an individual decision. Perhaps many of the modern realists do not care, since for them the important point is the indeterminate nature of the resulting body of law, however individual decisions are reached. But before I can accept their description of the total process of decisionmaking, I need to consider how individual decisions are reached. I suspect that the modern reahsts have given the matter much thought as well; I also suspect that at least soine of them see the decision of a given case not too differently from the result-oriented process described by the traditional realists. Perhaps the inodern realists are simply more charitable: The judge may not be startimg his thought process witl a conscious look at the bottoin line, but all too often his well-intentioned search for governimg principles will inevitably be influenced by a result-oriented preference.

I am not so naive as to deny that some judges in some cases permit personal predilections to determine the result. The equities sometimes matter, the rule of law is sometimes bent. Judges are not unmoved by the phight of soine accident victims or the overreaching of some creditors. I do assert, however, that the facile description of "result-oriented" decisionmaking must be applied with caution, for its wholesale invocation is simply false. The ordinary business of judges is to apply the law as they understand it to reach results with whicls they do not necessarily agree. They do this every day. Distasteful statutes are declared constitutional and apphed according to the legislators' evident intent; unwise decisions of administrative agencies are enforced; trial court rulings within the trial judge's discretion are upheld even though the reviewing judges would surely have ruled to the contrary; precedents of the local jurisdiction are followed that would be rejected as an initial proposition. Only infrequently does legal realism accurately describe the day-to-day decisionmaking of most judges. Were it otherwise, one would expect to find a high percentage of dissenting votes cast in a court like the Second Circuit, for example, whose judges span a considerable spectrum of pohtical, economic, and social perspectives. Yet in the inost recent year for which data are available, dissenting votes were cast in only $3.2 \%$ of the cases; the percentage for all the federal circuits was $3.7 \% .^{7}$ And I would maintain that only a small percentage of these relatively few disagreements can be explained on the basis of personal preferences. ${ }^{8}$

7. Telephone conversation with David Gentry, Chief, Noncriminal Branch, Statistical Analysis and Reports Division, Administrative Office of the United States Courts (Jan. 26, 1984). The percentages are based on all appeals submitted for decision to a panel or to an en banc court in the year ending June 30, 1983.

8. I must concede that the percentage of dissenting opinions is not necessarily a true reflection of all the occasions on which one meinber of a panel disagrees with the panel decision. A 
My purpose at this point, however, is not to cavil with the realists, but to identify the role of rational thought in a process that many of them perceive to be dominated by personal preferences. Two aspects inerit attention. First, even the judge prone to permit personal preferences to influence close cases can hardly escape the obhigation to pursue a process of rational thought in order to identify those issues of sufficient legal uncertainty to be vulnerable to resolution on extralegal considerations. Unless the realists are conteinplating a degree of judicial willfulness bordering on the tyrannical, they nust realize that the accepted body of law-constitutional, statutory, and decisional-exerts a profoundly restrictive effect upon the outcoine of inost legal confrontations, even those that find their way up to the federal courts of appeals. ${ }^{9}$ Surely on a three-member panel, the judge who would be result oriented, if he is to have any persuasive effect on his colleagues, must reason carefully from accepted legal principles to identify and isolate the new issue or the tension between contending doctrines that could be resolved by resort to personal preferences. And the very elucidation of the problein up to that last point of decisionniaking contributes to an orderly and rational development of the law, even if the final step and hence the final result have no firmer nooring than predilection.

Second, I venture to suggest that even in those instances when that final step is influenced by personal preferences, the tradition of our appellate system that obliges judges to articulate reasons forces the judge to select with care those reasons that can be enlisted for a favored result. And the expression of those reasons, even though subjectively tainted with rationalization, objectively makes some contribution to the legal structure. My point is that even when a result-oriented approach is used, the total decisionmaking process includes a significant component of rational thought.

When I turn to the other extreme-decisionmaking based on neutral principles, I encounter an initial difficulty in knowing just how far Professor Wechsler imtended to go. Rereading his well-known address twenty-five years after it was dehivered, what inipresses ine is the rather wide gulf between the modest nature of lis suggestion and the grandiose conception soine of the commentators have either praised ${ }^{10}$ or criti-

dissenting opinion and vote may be withheld for a variety of reasons. My perception is that the occasions wheu dissenting views are eutertained but not expressed would not significantly increase the perceutages of dissents set forth in the text.

9. For the view that the preexisting body of legal materials provides the "right answer" in all but the "hard cases," see R. Dworkin, TAKING RIGHTS SERIousLy 81-130 (1977); Dworkin, No Right Answer?, 53 N.Y.U.L. REv. 1 (1978) (revised and expanded froin Dworkin, No Right Answer?, in LAW, MORAL1TY, AND Soc1ETY 58 (P. Hacker \& J. Raz eds. 1977)).

10. See Greenawalt, The Enduring Significance of Neutral Principles, 78 CoLuM. L. REv. 982 (1978); Henkin, Some Reflections on Current Constitutional Controversy, 109 U. PA. L. REv. 637 
cized $^{11}$ him for advancing. With due respect to Professor Wechsler, he did select a phrase of ambiguous meaning. What is a "neutral principle"? Is it a principle totally lacking in value content? The Pythagorean theorem would surely qualify, but few serious disputes of law can be resolved by recourse to principles as devoid of values as that governing the sides of a right triangle.

Professor Wechsler's conception is far more attainable than his label might suggest. At one point he defines "neutral principlcs" as "standards that transcend the case at hand." 12 The result must not vary, he warns, whether the clami in suit has been advanced by "a Negro or a segregationist, a corporation or a Coinmunist." 13 For many claims, his caution will be widely accepted. Whatever principle resolves a claim to make a speech, met by a state's claim to avoid a riot, inust be applied with neutrahty whether the speaker is a Negro or a segregationist. Whatever principle resolves a claim to compensation for the taking of property, met by a state's claim to regulate the use of property, nuust be apphed with neutrality whether the property owner is a corporation or a Communist. ${ }^{14}$ But the very obviousness of these examples hints at the elusiveness of neutrality as a doctrine. A principle neutral as to parties should decide the free speech case and the property case, but all would agree that a plaintiff's identity as a black cannot be ignored when the claim is einployment discrimmation. Of course, this example merely illustrates the obvious point that a rule of positive law, whether constitutional or statutory, can make membership in a class relevant to an outcoine. But even that truism does not ex-

(1961); Brown, Book Review, 62 Colum. L. Rev. 386 (1962) (reviewing H. WeChSLER, PrINClPles, Politics, and Fundamental LaW (1961)). For some exainples of the neutral principles approach to constitutional criticism, see, for example, Henkin, The Supreme Court, 1967 TermForeword: On Drawing Lines, 82 HARv. L. Rev. 63 (1968); Kurland, The Supreme Court, 1963 Term-Foreword: Equal in Origin and Equal in Tille to the Legislative and Exeeutive Branches of the Government, 78 HARv. L. REv. 143 (1964).

11. See Miller \& Howell, The Myth of Neutrality in Constitutional Adjudication, 27 U. CHI. L. Rev. 661, 663 (1960); Miller \& Scheflin, The Power of the Supreme Court in the Age of the Positive State: A Preliminary Excursus (pt. 1), 1967 DukE L.J. 273, 281-83; Mueller \& Schwartz, The Principle of Neutral Principles, 7 U.C.L.A. L. Rev. 571 (1960); Richards, Rules, Policies, and Neutral Principles: The Search for Legitimacy in Common Law and Constitutional Adjudication, $11 \mathrm{G}_{\mathrm{A}}$. L. Rev. 1069 (1977); Rostow, American Legal Realism and the Sense of the Profession, 34 RockY MTN. L. Rev. 123 (1962); Shapiro, The Supreme Court and Constitutional Adjudication: Of Politics and Neutral Principles, 31 GEO. WASH. L. Rev. 587 (1963); Tushnet, Following the Rules Laid Down: A Critique of Interpretivism and Neutral Principles, 96 HARv. L. REv. 781 (1983); Wright, Professor Bickel, The Scholarly Tradition, and the Supreme Court, 84 HARv. L. REv. 769 (1971); Wright, The Supreme Court Can Not Be Neutral, 40 Tex. L. Rev. 599 (1962).

12. Wechsler, supra note 3, at 17.

13. Id. at 12 .

14. At least this must be so after it has been decided under some other principle that a corporation is a person within the meaning of the fourteenth amendment. Santa Clara County v. Southern Pac. R.R., 118 U.S. 394, 396 (1886). 
plain all instances in which the identity of a party is relevant. How neutral as to parties is the principle by which a court decides whether a corporation is entitled to the privilege against self-incrimination? ${ }^{15}$ I would not go so far as to suggest that neutrality is in the eye of the beholder, but I do contend that neutrality as to parties, or even the class of which they are members, cannot be universally maintained.

At another point, Professor Wechsler tells us that neutral principles are "criteria that can be framed and tested as an exercise of reason and not inerely as an act of willfuhress or will." 16 Again, note the modesty of the suggestion. Still later, we perceive the important clue that "neutrahty" for Professor Wechsler is not an absolute. Courts must decide, he urges, "on grounds of adequate neutrality." 17 And then appears the passage with which I find inyself in closest harnony. In deciding constitutional issues, he admonishes courts to inake a "principled appraisal, in respect of values that can reasonably be asserted to have constitutional dimension."18 The neutral principles that we are enjomed to seek are based on values, not the full range of values each individual judge might be tempted to enlist froin among a personal collection of political, economic, or social preferences, but the values that can reasonably be asserted to have legitimacy for the adjudication process. $^{19}$

Just as I noted aspects of rationality that attend result-oriented decisionmaking, my reciprocal point with respect to neutral principles is that their use is not free of value preferences. Agam, two aspects are worth notimg. However neutrally legal principles can be frained, close cases will involve a choice between at least two competing principles. Frequently they point in the saine general dircction. Sometimes they point in opposite or at least divergent directions. Whether the contending principles are complementary or contradictory, the judge who would reason from principles toward a result is obliged to select froin among competing principles, and what is worth considering is not only the process of reasoning from the selected principle, but, more important, the thinking that influenced the imitial selection. Values of some sort influenced the judge to believe that one of two competing principles was the inore pertinent.

The second role of values with respect to principled decisionmaking arises because the content of the relevant principles is not fixed in

15. See Hale v. Henkel, 201 U.S. 43, 74-75 (1906).

16. Wechsler, supra note 3 , at 11.

17. Id. at 15 .

18. Id. at 16 .

19. Writing in the context of constitutional adjudication, Wechsler referred to values of "constitutional dimension." Id. In transferring his thought to my discussion primarily of nonconstitutional issues, I have shifted the inquiry to values pertinent to the adjudication process. 
the manner of mathematical verities. Legal principles, evolved to assist the orderly resolution of disputes arising across the full range of human activities, reflect the untidiness of life. The content of such principles will not remain static. Their essence may continue in broad outline, but value judgments will affect their scope, force, and meaning at the margin. The duty of exercising reasonable care, for example, is an evolving concept.

So whether one sides witli those realists who see decisionmaking as an expression of preference for a result, with reasoning providing at best an ancillary function, or whether one aspires with Professor Wechsler toward neutral principles from which reasoning leads to results, a measure of both reasoning and expression of preferences will inevitably be involved. It is that combination of activity that characterizes the decision of close questions of law. I further suggest that when the process of adjudication is working well, when it functions in a manner entitled to be called legitimate, the values given preference will be neither as far ranging as many realists fear nor as narrow in scope as the phrase "neutral principles" implies.

\section{II \\ Legitimate VALUES OF ADJUDICATION-"INSTITUTIONAL" VALUES}

In a legitimate process of adjudication, I beheve there is an entirely appropriate, though limited, scope for some values, but not the political, economic, or social values that influence the judge's vision of what the world ought to be. The values that may properly play a part in influencing decisions are those that I think may fairly be described as "institutional" values. I lave in mind values that concern the judge's conception of the role of the courts and other sources of law, the judge's view of the federal system, and the judge's informed sense of the process of adjudication.

\section{A. The Role of the Courts and Other Sources of Law}

Every judge approaches decisionunaking with a value-laden view of the role of the courts. The view may change during the judge's career and it may vary with rcspect to certain fields of law. It may be a view the judge has thought deeply about, or it may be intuitively held without any overt expression to others or even to himself. Regardless of the degree of thought or expression, that view will inevitably exert a profound influence on the judge's decision of close cases. There will either be an eagerness or a reluctance to use judicial power. ${ }^{20}$ The

20. Let me emphasize that I am not referring to a reluctance to decide. That syndrome 
sense in which I refer to eagerness or reluctance to use judicial power concerns a use of judicial authority to intrude into real world events and alter their course. Judicial power, when used, inay shift inoney, stop actions froin being taken, or control actions to be taken. I have in mind a choice broader than the dichotoiny between judicial restraint and judicial activisin, which usually describes readiness to declare federal or state action unconstitutional or to frame adventurous and farreaching reinedies. I think there is a more pervasive dichotouny that divides judges on a wide variety of issues between those whose initial response to a claim for use of judicial power is, "That's what I'm here for" and those who say, "I'd better be careful."

A judge's view of judicial power inust of necessity also reflect soine view of the relationship between the courts and other sources of lawful authority such as the Congress, the executive branch, and the adininistrative agencies. These views, too, need not be static in time nor in subject matter, but they will significantly affect outcoines. Without digressing into a general discussion of statutory interpretation, let ine illustrate "institutional" values at work when I approach a dispute as to the ineaning of a statute.

I find it entirely unsatisfactory to make an initial choice between strict adherence to the words of a statute and a search for the overriding purposes of the statute-approaches that have coine to be called "hterahsm" and "purposive interpretation." Instead, I view Congress as an institution. I consider the nature of the legislative process and, in particular, the likelihood, or at least the ease, of statutory ainendment. $^{21}$ When construing a technical statute like the Internal Revenue Code, I notice that it is amended every year, usually in numerous respects, and that it is not unknown for a simgle taxpayer to get the ear of Congress and successfully whisper the virtue of an amendinent benefiting only a handful of taxpayers. That view inclines me to hterahisin. I tend to take the tax code as written and leave it to Congress to amend those provisions whose literal application produces a result they wish to reject. $^{22}$

On the other hand, my approach is different when the statute is a broad charter like 42 U.S.C. $\$ 1983$, or other civil rights statutes of more recent vintage. Statutes of this sort are enacted in an atmosphere of tension and high emotion. The wording of a provision will often be

unfortunately afflicts a handful of judges, and is indefensible. Reluctance to use judicial power is quite another matter. Of course, every decision of a case is in a sense an exercise of judicial power, for the court is decreeing that one of the parties has prevailed and the other has lost.

21. See United States v. Perdue Farms, lnc., 680 F.2d 277, 286 (2d Cir. 1982) (Newman, J., concurring).

22. See Ketchum v. Commissioner, 697 F.2d 466 (2d Cir. 1982). 
deliberately vague, refiecting an uneasy truce between contending forces; clarifying language will be rejected not because a inajority of Congress disapproves it, but because the proponents of the bill have secured agreement from diverse forces on the vague language and will not risk fracturing a fragile alliance with even a inodest ainendment. Once enacted, such legislation is rarely amended. In that context I am inclined away from literalism toward a construction that carries out the purposes that seein evident from all the traditional sources of legislative intent, even if the congressional mind entertained no precise solution to the dispute at hand. ${ }^{23}$

Let ine keep the point carefully circumscribed. The "institutional" values I assess when construing an Act of Congress will not bind me irrevocably to the text of every provision of the Internal Revenue Code, ${ }^{24}$ nor will they liberate me to read into a civil rights statute my private notion of what will best serve the Republic. ${ }^{25}$ But the "institutional" values will mcline ine toward literalism with the tax code and leave me at least more open to arguments based on legislative purpose when considering a civil rights act.

Other values come into play when the issue for decision turns on the degree of deference to be accorded the views of an adininistrative agency. Each side will argue the traditional maxims: The agency and the party whom the agency's decision favored will urge the court to defer to the agency's reasonable construction of the statute it is charged with enforcing; the party opposing the agency will remind the court of its ultimate responsibility to construe the statute. In resolving that type of dispute, "institutional" values concerning the functioning of administrative agencies have an undoubted influence. Agencies are nore reliable expositors of legislative mandates when they act as arbiters between contending parties than when the dispute concerns the agency's assertion of its own power in favor of or against a litigant. ${ }^{26}$ Again, this view of agency operation will have a limited role; traditional approaches to statutory construction and honest application of the substantial evidence rule will provide the answer to inany disputes. But there are close questions for which "institutional" values will be a helpful guide to the result.

\section{B. Federalism}

Just as a judge is inevitably influenced by the values he or she attaclies to courts as an institution and to the other governmental imsti-

23. See Thamel v. East Hartford, 373 F. Supp. 455 (D. Conn. 1974).

24. See Aetna Casualty \& Sur. Co. v. United States, 568 F.2d 811 (2d Cir. 1976).

25. See Bryan v. Koch, 627 F.2d 612 (2d Cir. 1980).

26. See Greater New York Hosp. Ass'n v. Blum, 634 F.2d 668, 673 (2d Cir. 1980). 
tutions that are sources of law, so a judge functioning in a federal system is mevitably influenced by values associated with his or her view of federahism. Again, let me try to place limits on that thought. I do not mean that each judge is free to construct and apply a wholly personal view of federahism. The federalism slate is no more pristine than any other on which the judge writes. The origin of the states, the formation of the Union, the adoption of the Constitution, the Civil War, the Reconstruction Amendinents, the realities of national power in post-New Deal America - in short, all of our history and all of our practice limit the range within which a judge is entitled to have views about federaIism. But some range exists. The most thorough and conscientious study of all the available materials will not yield the one correct view of the proper functioning of the federal system. Federalism, in its many applications, presents choices. The issue nuay be the scope of a state's immunity from congressional mandate, ${ }^{27}$ or the degree to which a state conviction may withstand the scrutiny of a federal court in a liabeas corpus proceeding ${ }^{28}$ or the appropriate sphere for state law tliat affects either federal causes of action ${ }^{29}$ or the federal trial of state causes of action. ${ }^{30}$ Judges considering all of these issues will be influenced to some extent by the values they associate with federalism.

\section{The Adjudication Process}

A final set of "institutional" values, less frequently identified than those I have mentioned, concerns the judge's perception of the process of adjudication. The decision of every case yields a rule of law, perhaps a very narrow rule that applies, if not just to the pending case, at least only to that handful of circumstances that closely resemble the facts in the hitigation. But many rules are broader, intended to apply to a wide range of situations only generally similar to the pending case. Then, too, some rules expected to have only narrow application acquire a life of their own, exerting an impact beyond what was expected at their aumouncement. Whether of narrow or broad scope, rules of law have "mstitutional" values associated with them that influence their selection. Again, at the risk of repetition but in the lope of avoiding misunderstanding, by "imstitutional" values I do not mean the judge's perception of whether the rule is good or bad pohtics, economics, or sociology. The "institutional" values that I believe may legitimately

27. Compare National League of Cities v. Usery, 426 U.S. 833 (1976), with EEOC v. Wyoming, 103 S. C. 1054 (1983).

28. See Sumner v. Mata, 449 U.S. 539 (1981).

29. See International Union, UAW v. Hoosier Cardinal Corp., 383 U.S. 696 (1966).

30. Compare Erie R.R. v. Tompkins, 304 U.S. 64 (1938), with Swift v. Tyson, 41 U.S. (16 Pet.) 1 (1842). 
influence a judge's selection of a rule of law relate to the operation of that rule within the context of a process of adjudication. Let me identify soine of those values.

One salient value concerns whether or not the rule will yield sound predictions as to its future application. If the rule depends for its application on the presence of only one or two essential facts, a reliable prediction of when the rule will be invoked may be made. But if the rule requires consideration of numerous facts and circumstances, it will be far more difficult to anticipate low subsequent courts will assess the various combinations of facts and circumstances that are likely to arise. Sornetimes the factual inquiry required to apply sucl a rule is simply not worth the refined results obtained. ${ }^{31}$ This does not mean that a rule of predictable application is preferable in all circumstances. Frequently a rule triggered by only one or two facts creates unfairness because of its unyielding failure to adjust to a range of pertiment factors. Selection of a rule often represents a choice between the virtue of predictability and the virtue of fairness or at least comprehensiveness. Predictability has a value, but not necessarily a paranount value. What value a judge assigns to predictability in a given context will influence the attractiveness of the rules available for selection.

Closely related to the predictability of a rule in operation is its ease of compreliension. Judges realize that rules are not selected for their virtue in the abstract. Rules of law are implemented botll within the system of adjudication and in the affairs of those governed by the rules in contemplation of adjudication but witlout resort to it. Within the context of adjudication, an appellate judge ought to consider how well a rule will be understood by trial judges in their applications of the rule, and low well they will be able to make it clear to jurors who must

31. An interesting example is Prosise v. Haring, 667 F.2d 1133 (4th Cir. 1981), affd, $103 \mathrm{~S}$. Ct. 2368 (1983). The issue was whether a plea of guilty to a state charge precludes litigation in federal court of a damage claim under 42 U.S.C. $\S 1983$ (1976) for an unlawful search and seizure. The Fourth Circuit considered the possibility that in some cases the evidence seizcd would be so crucial to the state's case (and presumably the ground for challenging the search so weak) that a guilty plea could fairly be taken as an acknowledgement that the defendant thought it was not worth litigating a suppression motion. The court observed that a factual inquiry could be made in each case to determine the significance of the guilty plea. However, the court rejccted a case-bycase factual inquiry in favor of a general rule agamst preclusion: "[O]n balance the game is not worth the candle. The question is so likely to be one incapable of fair and expeditious resolution that we believe a general rule of non-preclusion should obtain with respect to search and scizure issues in guilty plea cases." 667 F.2d at 1141.

In affirming, the Supreme Court simply pointed out that a guilty plea could be motivated by various considerations. "Therefore, Prosise's decision not to exercise his right to stand trial cannot be regarded as a concession of any kind that a Fourth Amendment evidentiary challenge would fail." $103 \mathrm{~S}$. Ct. at 2377 (emphasis added). Thus, the Supreme Court adopted a gcneral rule of nonpreclusion because a motivation warranting preclusion unight not exist in some cases. The Fourth Circuit adopted the general rule because it thought it was not worth dctermining in cach case whether a motivation warranting preclusion actually existed. 
hear it in a jury charge and apply it in the course of jury deliberations. Beyond the context of adjudication, yet in contemplation of it, an important value of a rule lies in its ability to be understood by lawyers who must advise clients, and, nore importantly, in its ability to be understood by inembers of the public affected by it, both those who receive the formal advice of lawyers and those whose conduct is guided by an untutored, nore osmotic coinprehension of the law. Again, a rule will not be selected or formulated simply because its clarity promotes compreliension. But clarity is a value properly to be assessed, and this value will influence decisionmaking.

A third operational value of a rule is the likely availability of evidence necessary to its application. In the abstract a rule may seein to be an eminently sensible primciple by which a class of disputes ought to be resolved. Yet it may be inadequate if it depends for its application on the presentation of proof not likely to be adduced. Of equal concern is the risk that the rule makes decisive a fact likely to be decided incorrectly. For exainple, it is commonplace to point out to juries that we cannot see into a person's mind to determine with certainty his intent, and we therefore permit the inference of intent from surrounding facts and circumstances. Inevitably the factfinder, whetlier jury or judge, will sometnnes be wrong in a conclusion about a person's intent. I suggest it is pertinent, in deciding whether to adopt a rule that turns on a person's intent, to assess, however intuitively, how likely we are to determine intent correctly, and how serious are the consequences of an incorrect determination. Having expressed that caution, $I$ must point out that whatever doubts might arise to incline a judge away froin a rule pivotimg on an elusive fact like intent will be inet by equally grave concerns as to the worth of a rule that abandons what inay be the inost relevant fact, and accepts as decisive soine less relevant fact, albeit one more likely to be determined correctly.

The difficulties of proof and the likelihood of incorrect factinding have generated a set of ancillary rules within the process of adjudication. We call these rules presumptions and burdens of proof. We aid the person for whom evidence may not be readily available witl a presumption that some ultimate fact is true. We try to ininimize the risk and consequences of incorrect factinding by raising the burden of proof and assigning the burden of persuasion, or at least the burden of producing evidence, to the side thought nore able, by virtue of access to information, to avoid an erroneous factual determination. How well these ancillary rules have succeeded in performing their assigned tasks is a question that has troubled many scholars. I venture no evaluation, though I adnit to some doubts. My point is that in selecting froin among competimg principles or formulating new ones, judges ought to 
evaluate the likelihood that evidence will be available and the risks of incorrect factfinding, and as they make those evaluations, they must necessarily give some consideration to the efficacy of these ancillary rules of presumptions and burdens of proof by which we try to reduce the risks of erroneous factfinding.

A final operational value is a consequence of the concerns just noted-namely, the ease with which a rule of law may be manipulated or even evaded by the shrewd or the corrupt. Rules of law are intended to be obeyed. There may be infrequent instances when the moral imperative of a rule justifies its adoption within a system of law, even though compliance is not likely to be obtained. But a legal system cannot afford inany luxuries of that sort. If a few rules are aspirations, unost inust be commands. This does not mean that judges should constantly measure the likelihood of public approval. It does mean that a legitimate value in the selection of rules of law is the likelihood that rules will be obeyed in the generality of instances and enforced when necessary. It is not the business of courts to sow the seeds of anarchy. Public toleration of a rule is relevant to its adoption. If the rule is capable of easy evasion, its observance will tend to erode. Lack of voluntary comphiance will becoine known, and lack of enforcement will be obvious. Of course, judges are not necessarily very good at predicting whether a rule will enjoy widespread observance and whether enforcement will be achievable. Nevertheless I suggest they ought to cast an eye on such considerations. Their assessment of values of this sort may not be decisive, but it will be relevant to an outcoine.

Indeed, that is iny point with respect to all of the institutional values I have been considering. A judge's view of courts and other sources of law, his view of the federal system, and his view of the process of adjudication all comprehend values that are relevant to the decision of cases. These institutional values influence the outcome of close questions. I do not know how often they are decisive. I suspect the frequency is very low, if one considers the universe of all cases that come to the appellate courts. If attention is directed only to the small category of cases where the issue can fairly be said not to be precisely governed by the prevailing body of law, then the opportunity for the impact of institutional values is, of course, much larger.

III

The Distinction Between Institutional Values and LEGAL REALISM

It is fair to ask whether, in accepting even a narrow role for these institutional values, I am noving perilously close to the legal realists and accepting a process of adjudication that selects results and rational- 
izes backward from them. I would answer im two ways. First, the legal realists with whom I choose to contend are satisfied that the judge's attention is focused on the primary results of adjudication: who wims and who loses, or perliaps whether the class to which one side belongs ought generally to win and the class to which the other side belongs ought generally to lose. By contrast, my concern is not at all with primary results. If I focus my attention on the value of a rule that inheres in the rule's ease of application, predictability, susceptibility of proof, or likelihood of compliance, I am attracted to the rule because of what might be called its secondary result-promotimg the pervasive value of the orderly development of the law-not its primary result of determining who wims the dispute at hand. If I am bemg conscientious, I will ignore the primary result of the rule, or, more realistically, try to minimize the impact of my mevitable awareness of what the primary result will be.

My second response is that the institutional values I think may properly be considered operate within narrow ranges of decisionmaking, already circumscribed by constitutional, statutory, and decisional law. Even within those ranges, I am not free to assign entirely personal values to these institutional considerations, but must accept, in the mam, the institutional values commonly accepted by the legal system in which I function.

However, I cannot and do not deny that even these limitations leave a judge some room to choose. It could not be otherwise if what is expected of a judge is judgment, not computation. So while I do not claim that consideration of institutional values will yield principles of perfect neutrality, I do assert that they properly influence the selection and development of principles of adequate neutrality-that disinterestedness that perimits rational thought to evolve an outcome, independent of the judge's preference as to which side should win or lose the case at hand.

Still, I must admit that I have not satisfactorily explaimed by what process a judge ought to assess these institutional values that $I$ have identified. Once the judge notices, for example, that the choice between two contending legal principles presents a subsidiary choice between the value of predictability and the value of comprehensiveness, how is that subsidiary choice to be made? I have no pat answer to that question. But I do not believe that my uncertainty imphes a surrender to the modern realists who insist that law is essentially indeterminate whenever close questions of law are encountered. Of course every judge will not assess institutional values the saine way. For some the value of predictability or the value of comprehensiveness in a given context will be a matter of faith or intuition or guesswork. But other 
judges can and will do better. Available data will be examined. Historical trends will be noted. Sound arguments will be advanced. In short, even $\mathrm{m}$ the assessment of values, a rational process will play a part. It is my conviction that in the marketplace of values relevant to the judicial process, those values allied with sound arguments are the more likely to prevail.

\section{CONCLUSION}

The modern realists may be riglit some of the time. The law may be indeterminate in some of its applications. But if my faith in rationality is not wholly warranted, neither is their wholesale rejection of rationality. The decision of close cases need not be a random process. The power of constructive thought can be brought to bear to loold to an acceptable minimum the instances where law is not determinate. And consideration of institutional values can play an important part in a rational process of selecting from among competing legal principles and evolving new ones. If I did not believe such a process was occurring in the decision of most cases, I would not wish to be a judge.

Fimally, whether or not I have accurately positioned imstitutional values somewhere between the aspiration for neutral principles and the rationalizations described by the legal realists, I hope I liave illuminated the virtue of focusing attention on these values. In some instances judges will articulate them and try to demonstrate their role in the resolution of a disputed point of law. More often, however, institutional values will remain implicit in the appellate opinion. Judges are frequently unaware of the imstitutional values that influenced their decisions, even though their intuitive assessment of these values was of some significance to the outcome. That leaves an important task for those qualified to offer inforined criticism. Much legal commentary has been content to analyze the fornal reasoning of an appellate opinion or to assess the merits of a result. I do not suggest that these are modest tasks, nor do I deny the worth of such endeavors. Rather, I urge something in addition. I suggest that legal scliolarslip ought to identify the imstitutional values implicit in the decision of a seriously disputed poimt of law, and assess the appropriateness of perinitting those values to have some influence on the outcome. I think sucl analysis will provide fresh insights imto the nature of judicial decisionmaking and contribute to the pervasive value that frequently provides guidance for me-the orderly development of the law. 